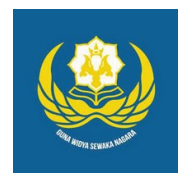

Jurnal Analogi Hukum

Journal Homepage: https://ejournal.warmadewa.ac.id/index.php/analogihukum

\title{
Pemberantasan Pungutan Liar Sebagai Tindak Pidana Korupsi Pada Dinas Perhubungan Kabupaten Badung
}

\author{
Ni Komang Laksmi Ari Widya Pramesti*, Simon Nahak dan I Wayan Arthanaya \\ Universitas Warmadewa, Denpasar-Bali, Indonesia \\ *ariwid.p@yahoo.com
}

How To Cite:

Pramesti, N, K, L, A, W., Nahak, S., Arthanaya, I, W. (2021). Pemberantasan Pungutan Liar Sebagai Tindak Pidana Korupsi Pada Dinas Perhubungan Kabupaten Badung. Jurnal Analogi Hukum. 3 (1). 57-61. Doi: https://doi.org/10.22225/ah.3.1.3034.57-61

\begin{abstract}
Corruption is an extraordinary crime (extraordinary crime) of the government and when law enforcement in its handling must have a strong determination and power. One of the criminal acts of corruption is illegal levies, acts of retribution which are a social phenomenon that existed before the Indonesian State became independent. Along with the development of technology and information on developments in the era of globalization has a huge influence on human life and civilization. Stimulates the human mind, giving rise to various problems that have positive and negative effects. These problems can be examined as follows: 1) what is the role of the community in eradicating Illegal Levies as a Corruption Crime? 2) How is Law Enforcement of Illegal Levies as a Corruption Crime at the Badung Regency Transportation Service? This presentation uses Empirical research methods, and requires primary data as the main data in addition to secondary data. The role of the community in efforts to prevent and eradicate Corruption Crime is contained in article 41 (1) Law No. 20 of 2001 changes to Law No. 31 of 1999 The Corruption Act which we know more about the Law on the Eradication of Corruption Crime. Prevention and eradication of Corruption Crimes in the form of seeking, obtaining, providing data or information on Corruption Crimes and the right to submit suggestions and opinions responsibly for the prevention and eradication of Corruption Crimes. Wild levies are actions that are intentionally carried out to enrich themselves, groups, or corporations.
\end{abstract}

Keywords: Corruption; imposts; wild

\begin{abstract}
Abstrak - Tindak pidana korupsi merupakan kejahatan luar biasa (extra ordinary crime) pemerintah dan apaat penegak hukum dalam penangannanya harus mempunyai tekad dan usha yang kuat. Salah satu tindak pidana korupsi adalah Pungutan liar, perbuatan pungungutan yang merupakan suatu gejala soasial yang telah ada sebelum Negara Indonesia merdeka. Seiring Berkembangnya teknologi dan informasi perkembangan di era globalisasi memberi pengaruh yang sangat besar pada kehidupan dan peradaban manusia. Merangsang pikiran manusia, sehingga menimbulkan berbagai masalah yang dampaknya positif dan negatif. Permasalahan tersebut dapat dikaji sebagai berikut: 1) Bagaimana peran serta masyarakat dalam pemberantasan Pungutan Liar sebagai Tindak Pidana Korupsi? 2) Bagaimana Penegakan hukum Pungutan Liar sebagai Tindak Pidana Korupsi pada Dinas Perhubungan Kabupaten Badung?. Penyajian ini menggunakan metode penelitian Empiris, dan memerlukan data primer sebagai data utama disamping data sekunder.Peran masyarakat dalam upaya pencegahan dan pemberantasan Tindak Pidana Korupsi terdapat dalam pasal 41 (1) Undang-Undang No. 20 Tahun 2001 perubahan atas Undang-Undang No. 31 Tahun 1999 Undang-Undang Tindak Pidana Korupsi yang lebih kita kenal UU Pemberantasan Tindak Pidana Korupsi. Pencegahan dan pemberantasan Tindak Pidana Korupsi dalam bentuk mencari, memperoleh, memberikan data atau informasi Tindak Pidana Korupsi dan hak menyampaikan saran dan pendapat secara bertanggung jawab terhadap pencegahan dan pemberantasan Tindak Pidana Korupsi. Pungutan liar merupakan tindakan yang sengaja dilakukan untuk memperkaya diri sendiri, kelompok, atau koorporasi.
\end{abstract}

Kata Kunci: Korupsi; Pemberantasan; Pungutan Liar 


\section{Pendahuluan}

Kepastian dan keadilan merupakan salah satu tujuan hukum yang paling banyak dibicarakan, karena keduanya dinilai sebagai sasaran utama yang hendak dicapai oleh manusia melalui pelaksanaan hukum (Artadi, 2006). Indonesia adalah negara yang berdasarkan hukum (rechstaat), tidak berdasarkan kekuasan belaka (machstaat). Tujuan hukum mempunyai sifat universal seperti ketertiban, ketenteraman, kedamaian, kesejahteraan dan kebahagiaan dalam tata kehidupan bermasyarakat. Perkembangan teknologi dan informasi membawa pengruh besar pada kehidupan dan kesadaran manusia yang telah merangsang pikiran manusia untuk terus berinovasi yang dampaknya bisa positif dan negatif. Penanggulangan Korupsi melalui penindakan dilakukan dengan upaya penegakan hukum oleh aparat pemerintah. Dalam hukum pidana ada beberapa, yaitu: Kepolisian, Kejaksaan, Hakim, Advokat, dan KPK. Tindak pidana korupsi merupakan tindak pidana penyuapan manipulasi dan perbuatan melawan hukum yang dapat merugikan perekonomian negara, dan merugikan kesejahteraan rakyat. Perbuatan yang merugikan perekonomian negara yaitu korupsi dibidang materil, sedangkan korupsi dibidang politik berupa memanipulasi pemungutan suara dengan cara penyuapan, dan campur tangan yangmempengaruhi kebebasan memilih komersiliasi pemungutan suara pada lembaga legislatif atau pada keputusan yang bersifat administratif dibidang pelaksanaan pemerintah (Djaja, 2009). Salah satunya kasus tindak pidana korupsi adalah pungli, yang mana pelaku melakukan dugaan tindak pidana korupsi dengan sengaja menerima uang tanpa hak atau melakukan pungutan berupa uang untuk penguji kendaraan bermotor atau uji KIR. Tersangka selaku staf penguji pada Dinas Perhubungan Kabupaten Badung, melanggar PERDA tentang Retribusi Pengujian Kendaraan Bermotor No. 27 tahun 2011, dan pasal 12 huruf $b$ atau pasal 12 huruf e UUDRI No. 20 Tahun 2001 Perubahan atas UUD RI No. 31 Tahun 1999 tentang pemberantasan Tindak Pidana korupsi.

Berdasarkan urian diatas, dapat dirumuskan pokok permasalahan yang akan dibahas secara lebih mendalam pada penelitian ini sebagai berikut :

Bagaimanakah peran serta masyarakat dalam pemberantasan Pungutan Liar sebagai Tindak Pidana Korupsi?

Bagaimanakah Penegakan hukum Pungutan Liar sebagai Tindak Pidana Korupsi pada Dinas Perhubungan Kabupaten Badung?

Berdasarkan rumusan masalah tujuan dari penelitian ini yaitu :

Untuk mengetahui bagaimana peran serta masyarakat dalam pemberantasan Tindak Pidana Pungutan Liar.

Untuk mengetahui penegakan pungutan liar di Dinas Perhubungan Kabupaten Badung.

\section{Metode}

Dalam Penelitian hukum yang digunakan adalah metode penelitian empiris yaitu penelitian yang objeknya masyarakat, dan penelitian lapangan. Memerlukan data primer sebagai data utama disamping data sekunder (bahan hukum). Menggunakan data primer yang diperoleh langsung dari responden dan nara sumber mengenai obyek yang diteliti berupa: Hasil kuesioner atau angket, hasil wawancara dan hasil observasi (Ibrahim, 2016). Sumber data dalam penelitian ini adalah sumber data dimana data diperoleh dari hasil penelitian empiris, yaitu penelitian yang dilakukan langsung didalam masyarakat, sumber yang digunakan dalam penelitian ini agar tercapai kelengkapan dan keterpaduan data yaitu :

\section{Data primer}

Data asli yang diperoleh langsung dari sumbernya. Pengambilan data yaitu dengan cara meminta keterangan dan penjelasan dari pihak yang terkait dengan permasalahan yang diteliti. Dalam hal ini adalah data yang berasal dari lokasi penelitian yang diperoleh di Dinas Perhubungan Kabupaten Badung.

\section{Data Sekunder}

Yaitu sejumlah keterangan atau fakta-fakta yang secara tidak langsung sepertimembaca buku, literature, artikel dan tulisan-tulisan ilmiah lainnya.

Dari hasil permasalahan yang diteliti maka teknik pengumpulan data yang digunakan yaitu hasil kuesioner atau angket, hasil wawancara, perundang-undangn dan putusan hakim serta literatur-litelatur maupun bahan hukum lainnya yang dilakukan untuk mendapatkan dan mengumpulkan data yang akurat.

\section{Hasil Penelitian dan Pembahasan}

\section{Peran Serta Masyarakat Dalam Pemberanta- san Pungutan Liar Sebagai Tindak Pidana Korupsi}

Korupsi merpakan tindakan yang sangat 
merugikan bagi Negara Perlu pemantauan dan evaluasi terhadap seluruh pekerjaan atau kegiatan pemberantasan korupsi agar diketahui capaian yang telah dilakukan mengenai peemberantasan Tindak Pidana Korupsi. Dengan diadakan pemantauan dan evaluasi agar dapat dilihat strategis atau program yang sukses dan gagal. Dengan program yang sukses bisa dilanjutkan, sedangkan yang gagal dapat diperbaiki dan dicari penyebabnya kegagalan tersebut (Hamzah, 2008).

Pembentuk undang-undang itu tertuang dalam rumusan Pasal 41 (3) UU RINo. 20 Tahun 2001 Perubahan Atas UU RI Nomor 31 Tahun 1999 tentang Pemberantasan Tindak Pidana Korupsi, Bentuk peran serta tersebut, dalam Pasal 41 (2) telah ditentukan wujudnya.

Dengan upaya mengoptimalkan peran serta masyarakat dalam pencegahan dan pemberantasan tindak pidana korupsi, aparat pemerintah atau pejabat pemerintah dan KPK sekiranya berkenan untuk memberikan jawaban atau keterangan sesuai dengan tugas dan fungsinya masing- masing.

Pungutan Liar sangat merugikan masyarakat dalam pelayanan publik dan juga mencemarkan nama baik pribadi maupun instansi pemerintah. Beberapa faktor seseorang melakukan Pemungutan, sebagai berikut Penyalahgunaan Wewenang, Faktor Mental, Faktor Ekonomi, Faktor Kultural dan Budaya Organisasi, Terbatasnya Sumber Daya Manusia, Lemahnya Sistem kontrol dan Pengawasan Oleh Atasan.

Dinas Perhubungan sebagai satu badan yang menangani lancarnya hubungan jalur darat, laut dan udara dalam hal retribusi maupun non retribusi kerap terjadi tindakan pemungutan dilakukan pegawai ataupun pejabat Negara didalamnya.Saat menjalankan tugasnya, aparat memang sering menarik uang ekstra dari layanan yang diberikan kepada warga masyarakat untuk kepentingan pribadi (Wibawa, F.M, \& Habibah, 2013).

Penegakan hukum, olehNegara hukum yang dikemukakan oleh Sudikno Mertokusumo merupakan salah satu unsur untuk menciptakan ketentraman, keamanan atau memulihkan keseimbangan dalam tatanan masyarakat yaitu penegak hukum (Mertokusumo, 2008).

Dengan demikian dirumuskan bahwa penegakan hukum merupakan suatu bagian dari pembangunan hukum yang mengarah pada upaya penerapan hukum untuk mengembalikan keamanan, ketentraman dan keseimbangan da- lam tatanan kehidupan masyarakat. Penegakkan hukum dilakukan oleh pemerintah Indonesia Dalam konteks pelayanan publik, Presiden melalui kebijakan ini menghendaki adanya tindakan tegas terhadap praktik pungutan liar (pungli). Kredibilitas pengawasan terhadap lembaga penegak hukum, khususnya pengawas internal. Presiden harus memastikan bahwa penegak hukum tidak akan melindungi oknum penegak hukum yang melakukan pungli (esprit de corps). Jika perlu sistem pengawasan internal diintegrasikan dengan sistem pengawasan eksternal.

\section{Penegakan hukum Pungutan Liar sebagai Tindak Pidana Korupsi pada Dinas Perhub- ungan Kabupaten Badung}

Salah satu kasus korupsi adalah pungutan liar, dimana tersangka melakukan pungutan berupa uang sebesar Rp. 250.000,- (dua ratus lima puluh ribu rupiah) untuk penguji kendaraan bermotor atau uji KIR mobil model pick up merek Daihatsu, warna hitam nopol : B 9214 NB, atas nama PT. Pilar Garba Inti dengan buku Kir Nomor : M 095862 yang dikeluarkan oleh pemprov DKI Jakarta Pada Dinas Perhubungan Kabupaten Badung. Tersangka dikenakan sanksi pidana, yaitu berupa:

Pasal 12 huruf b UU NRI No. 20 tahun 2001 Perubahan Atas UU NRI Nomor 31 tahun 1999 Tentang Pemberantasan Tindak Pidana Korupsi.

Pasal 12 huruf e UU NRI Indonesia Nomor 20 tahun 2001 Perubahan Atas UU NRI Nomor 31 tahun 1999 Tentang Pemberantasan Tindak Pidana Korupsi; dan

PERDA Kabupaten Badung tentang Retribusi Pengujian Kendaraan Bermotor No. 27 tahun 2011.

Berdasarkan hasil wawancara penulis dengan beberapa pegawai dan masyarakat tentang pungutan liar tersebut dapat disimpulkan bahwa pungutan liar tersebut memang sudah menjadi budaya dalam masyarakat. Bahwa suatu pungutan yang dilakukan oleh oknum baik sipil, pegawai negeri atau BMN yang tidak didasari oleh peraturan yang dikeluarkan oleh pemerintah. Pungutan yang disebut pungli yaitu bisa berwujud distribusi dan iyuran-iyuran yang tidak bisa dipertanggungjawabkan keperuntukannya atau keperolehannya merasa tidak dirugikan. Upaya pemberantasan pungli tersebut dilakukan dari dirisendiri dan dengan memperketat peraturan yang ada dengan meminimalisir celah-celah yang ada yang 
digunakan untuk melakukan pungutan tersebut Untuk memberantas pungli masyarakat yang mengetahui praktek atau tindakan tersebut harus segera melapor kepada aparat penegak hukum bahwa dalam wilayahnya terjadi kegiatan pungli tersebut. Dalam pemberantasan pungli tersebut semua kalangan berhak berpartisipasi, tetapi hal ini tidak dapat dilaksanakan selama masyarakat dapat menghilangkan budaya memberikan sesuatau untuk mengupayakan hal-hal diluar dari ketentuan atau aturan hukum yang ada dan Kesadaran masyarakat yang paling terpenting untuk melaporkan kegiatan pungli tersebut. Penegakan hukum bagi pelaku pungli dengan cara membentuk badan khusus yang membidangi tentang pemberantasan pungli yang ada dimasyarakat, pemerintah saat ini juga suda membentuk satgas saber pungli disertai undangundang dasar dan peraturan pemerintah tetapi hal tersebut belum memiliki efek jera terhadap pelaku pungli dimasyarakat. Sesuai dengan aturan yang ada dengan didampingi oleh aparat penegak hukum yang terkait dengan hal tersebut dan jika dilakukan di dalam suatu instansi maka kpk berhak menindak hal tersebut. Banyak sekali kepala daerah yang tertangkap tangan melakukan praktek jual beli jabatan, dan banyak juga pegawai negeri sipil yang tertangkap tangan melakukan tindakan pungli pada uji kir dengan menawarkan keringanan atau mempercepat proses pengurusan uji kir tetapi dengan imbalan di bayar lebih dari ketentuan yang ada, ada juga pejabat daerah yang melakukan atau memintak proyek terhadap pengembangan dan masih banyak lagi. Penyebab terjadinya pungli karena perekonomian seseorang tersebut, sehingga mereka melakukan pungutan yang tidak sesuai dengan aturan yang ada demi perekonomiannya.Peran masyarakat dalam memberantas pungli dengan cara tidak memberikan uang terimakasi atau imbalan kepada aparat pemerintah atau orang yang melakukan pungli tersebut. Dan memberikan Penegakan hukum terhadap pelaku pungli berupa sanksi dan langsung melaporkan kejadian pungli tersebut.

Berdasarkan data tentang pungli yang penulis peroleh di lapangan, disampaikan bahwa jumlah pengaduan masih relatif kecil yakni sebanyak 77 aduan. Rinciannya, bidang perizinan pengawasan $(3,8 \%)$, hibah dan bansos $(2,5 \%)$, pendidikan $(23,3 \%)$, dana desa $(2,5 \%)$, pelayanan publik $(22 \%)$, pengadaan barang dan jasa $(1,2 \%)$, serta lain-lain $(44,2 \%)$. Tim saber pungli juga sudah melakukan pencegahan ke kabupaten dan kota. Sementara Gubernur Bali menekankan pungutan liar merupakan pelanggaran hukum dan harus diberantas serta semua aparat yang melakukan pungutan liar harus ditindak tegas. Semua instansi diwajibkan membuat prosedur secara jelas dan harus dipatuhi, dan dilaksanakan pengawasan. Jika ada anggota di instansi melaksanakan pungli maka atasannya harus juga disidik apabila dana pungli mengalir ke atas.

\section{Simpulan}

Dalam upaya pencegahan dan pemberantasan tindak pidana korupsi, peran serta masyarakat dinilai sangat perlu dijalani dengan prinsip demokrasi yang memberikan hak kepada masyarakat untuk memperoleh informasi tentang pencegahan dan pemberantasan tindakan pungutan liar tersebut. Dengan demikian pemberantasan tindakan tersebut menjadi optimal. Hak dan tanggungjawab masyarakat dalam upaya pencegahan dan pemberantasan Tindak Pidana Korupsi diatur dengan tegas pada pasal 41 UU NRI No. 20 tahun 2001 Perubahan atas UU NRI No. 31 tahun 1999 tentang Pemberantasan tindak Pidana Korupsi, Tata Cara Pelaksanaan Peran Serta Masyarakat dan Pemberian Penghargaan dalam pencegahan dan Pemberantasan Tindak pidana korupsi diatur juga dalam Peraturan Pemerintah RI No. 71 tahun 2000.

Penegakan hukum pungutan liar sebagai tindak pidana korupsi, dalam meningkatkan pelayanan masyarakat dibidang pelayanan pengujian kendaraan bermotor di Dinas Perhubungan Kabupaten Badung. Pemerintah mengatur mengenai retribusi pengujian kendaraan bermotor sehingga dalam penyelenggaraan prinsip dan penentuan tarif retribusi diharapkan dapat dapat meningkatkan mutu pelayanan pemerintah dengan tujuan kepentingan dan manfaat umum untuk dinikmati oleh semua orang atau masyarakat. Pungutan liar diatur dengan tegas padaUU NRI Pembeerantasan Tindak Pidana Korupsi No. 20 tahun 2001 Perubahan atas UU NRI No. 31 tahun 1999, diatur juga dengan khusus dalam Peraturan Presiden Nomor 87 Tahun 2016 Tentang Satuan Tugas Sapu Bersih Pungutan Liar, juga diatur dalam PERDA Kabupaten Badung tentang Retribusi Pengujian Kendaraan Bermotor No. 27 tahun 2011.Berlakunya Peraturan Daerah ini, diharapkan dapat meningkatkan mutu pelayanan Pemerintah Daerah dengan tujuan untuk kepentingan dan manfaat umum dan dapat dinikmati oleh semua orang atau masyarakat.

\section{DAFTAR PUSTAKA}

Artadi, I. (2006). Hukum: Antara Nilai-Nilai Kepastian, Kemanfaatan Dan Keadilan. 
Hukum Dan Dinamika Masyarakat, Oktober. Retrieved from http:// jurnal.untagsmg.ac.id/index.php/hdm/ article/download/362/415

Djaja, E. (2009). Memberantas Korupsi Bersama KPK (Komisi Pemberantasan Korupsi). Jakarta: Penerbit Sinar Grafika.

Hamzah, A. (2008). Pemberantasan Korupsi Melalu Hukum Pidana Nasional dan Internasional. Jakarta: Raja Grafindo.

Ibrahim, J. (2016). Metode Penelitian Hukum Normatif dan Empiris. Depok: Prenadamedia Grup.

Mertokusumo, S. (2008). Mengenal Hukum Suatu Pengantar. Yogyakarta: liberty.

Wibawa, S., F.M, A. F., \& Habibah, A. (2013). Efektivitas Pengawasan Pungutan Liar Di Jembatan Timbang. Jurnal Ilmu Administrasi Negara, 12(2), 74-85. Retrieved from https:// jiana.ejournal.unri.ac.id/index.php/ JIANA/article/download/1721/1695 